\title{
PENGARUH JARINGAN PERDAGANGAN GLOBAL PADA STRUKTUR WILAYAH DAN KONFIGURASI SPASIAL PUSAT PEMERINTAHAN KESULTANAN- KESULTANAN MELAYU DI KALIMANTAN BARAT
}

\author{
Uray Fery Andi \\ Staf Pengajar, Program Studi Arsitektur, Universitas Tanjungpura Pontianak \\ E-mail:urayandi@yahoo.com
}

\begin{abstract}
ABSTRAK
Lokasi pusat-pusat pemerintahan kesultanan Melayu di Kalimantan Barat berada di sepanjang tepian sungai. Sungai menjadi faktor yang sangat penting dalam kehidupan kesultanan, yaitu terkait dengan fungsinya sebagai sumber kehidupan dengan beragan jenis flora dan fauna, sebagai aksesibilitas dan jalur transportasi serta komunikasi. Keterbatasan wilayah tepian sungai menyebabkan perkembangan pusat kesultanan melebar sepanjang tepian sungai karena wilayah daratan masih berupa hutan dan kurang aman. Perkembangan aktivitas perdagangan global pada masa pemerintahan kesultanan yang semakin pesat menyebabkan jalur sungai semakin ramai dilalui oleh pedagang lokal, regional dan internasional. Keberadaan kongsi dagang Belanda (VOC) hingga menjadi pemerintahan Hindia Belanda turut mempengaruhi perkembangan pusat-pusat pemerintahan kesultanan Melayu di Kalimantan Barat.Tujuan dari penelitian ini adalah untuk mengetahui pengaruh jaringan perdagangan global terhadap struktur wilayah Borneo Barat dan konfigurasi spasialpusat pemerintahankesultanan-kesultanan Melayu di Kalimantan Barat. Penelitian dilakukan dengan menggunakan metode sejarah yaitu dengan mengetahui perkembangan sistem jaringan perdagangan global dan korelasinya dengan sejarah pembentukan wilayah kesultanan. Hasil penelitian menunjukkan bahwa sistem dan jaringan perdagangan mempengaruhi struktur wilayah Borneo Barat dengan sistem hulu-hilir dan konfigurasi spasial wilayah pusat pemerintahan kesultanan Melayu yang terbatas dan melebar sepanjang tepian sungai.
\end{abstract}

Kata-kata kunci: jaringan perdagangan, struktur wilayah, konfigurasi spasial, kesultanan Melayu, Kalimantan Barat

\section{THE INFLUENCE OF GLOBAL TRADING NETWORK ON THE MALAY SULTANATES CENTRAL OF GOVERNMENT STRUCTURE AND SPATIAL CONFIGURATION IN WEST KALIMANTAN}

\begin{abstract}
Malay sultanates central government in West Kalimantan were located along the banks of the river. The river became very important factor in the life of sultanates, which was related to its function as a source of life with a variety of floras and faunas, as well as accessibility, transportation lines and communication. Limitations of the riverbank area led to the development of the center of sultanates which extended along the river banks, because land area were still forested and less secure. The development of global trade activities during the reign of sultanates, which grew rapidly, led to increasingly crowded river path, traversed by local, regional and international traders. The existence of Dutch trade partnership (VOC) and later became the Dutch East Indies, also influenced the spatial development of administrative centers in West Kalimantan Malay sultanates. The purpose
\end{abstract}


of this study was to determine the influence of global trading network on the spatial structure of Westeer Borneo Afdelling and on spatial configuration of the Malay sultanates region in West Kalimantan. The study was conducted using historical method, by mapping the development of a global trading network system and its correlation with the history of the region formation of the sultanates. The results showed that the trading systems and networks affected the structure of afdelling by upstream and downstream system, and the spatial configuration of the central region of Malay sultanates government became limited and spread along the riverbanks.

Keywords: trading network, regional structure, spatial configuration, Malay sultanates, West Kalimantan

\section{Pendahuluan}

Suatu kota dapat terbentuk karena adanya pengumpulan orang dan aktivitas ekonomi di suatu tempat atau yang biasa disebut dengan istilah aglomerasi ekonomi, yaitu berkumpulnya aktivitasaktivitas ekonomi di lokasi yang sama untuk menghasilkan manfaat ekonomi. Secara teoretis, kota dan pembahasan tentang sejarah kota seharusnya menyadarkan kita bahwa sebuah kota tidak terbentuk secara alamiah, kebetulan atau yang diatur oleh invisible hands yang tak memihak. Struktur dan pola ruang kota memiliki sejarah dengan proses pembentukannya yang dapat dilacak dan dianalisa secara jelas. Menurut Barnett (1974), bentuk kota adalah hasil dari suatu tindakan sengaja atau tidak sengaja serta spesifik dari berbagai kekuatan pribadi, kelompok, pemerintah, serta kepentingan masyarakat lokal, regional, maupun global. Perkembangan dan perubahan wujud kota sangat dipengaruhi oleh tingkat variasi dari berbagai unsur berdasarkan pada perkembangan sejarah dan proses pertumbuhannya. Proses pembentukan sebuah kota merupakan hal yang kompleks, dimana setiap kota memiliki latar belakang khusus dalam proses pembentukannya yang tercermin dalam wujud fisik ruang kotanya.

Proses pembentukan kota-kota di Kalimantan Barat, Indonesia, tidak terlepas dari sejarah perkembangan kesultanan-kesultanan Melayu. Sebelum menjadi kota-kota administratif dibawah negara kesatuan Republik Indonesia, kota-kota di Kalimantan Barat merupakan bagian dari wilayah kesultanan yang berdiri sendiri. Kesultanan-kesultanan Melayu di Kalimantan Barat berdiri dan terletak di sepanjang tepian Sungai Kapuas dan anak sungainya. Keberadaan Sungai Kapuas sebagai jalur transportasi dan komunikasi semakin penting ketika perdagangan global merambah wilayahwilayah kesultanan dengan potensi alamnya masing-masing. Masuknya VOC sebagai kongsi dagang Belanda, yang kemudian menjadi pemerintah Hindia Belanda, semakin memperkuat jaringan perdagangan global sepanjang Sungai Kapuas dan atar wilayah kesultanan. Kondisi ini menjadikan pusat-pusat pemerintahan kesultanan semakin sibuk oleh aktivitas ekonomi dan manusia dan menjadi cikal bakal perkotaan pada pusat wilayah kesultanan Melayu di Kalimantan Barat.

\section{Metodologi}

Penelitian dilakukan terhadap istana-istana kesultanan Melayu sebagai bangunan peninggalan sejarah kesultanan Melayu di Kalimantan Barat. Istana-istana kesultanan Melayu merupakan produk arsitektur yang telah mengalami berbagai kejadian-kejadian dan pengaruh-pengaruh dari masa lalu. Penelitian dilakukan dengan mengumpulkan data-data sejarah dan perkembangannya dari mulai berdirinya kerajaan hingga kini. Dari seluruh istana kesultanan yang ada di Kalimantan Barat diambil kasus 8 (delapan) buah istana yang masih ada, yaitu: 1) Istana Kesultanan Matan, Ketapang, 2) Istana Kesultanan Landak, 3) Istana Kesultanan Sintang, 4) Istana Kesultanan Sambas, 5) Istana Kesultanan Sanggau, 6) Istana Kesultanan Tayan, 7) Istana Kesultanan Mempawah, dan 8) Istana Kesultanan Pontianak.

Metode penelitian yang dipergunakan dalam penelitian ini yaitu interpretif sejarah. Penelitian interpretif sejarah merupakan jenis strategi penelitian naratif berdasarkan pada data-data historis. 
Penelitian interpretif secara spesifik merupakan upaya investigasi fenomena sosial-fisik dalam konteks yang kompleks secara naratif dan holistik (Groat \& Wang, 2002). Penelitian interpretif sejarah berhubungan dengan fenomena-fenomena yang terjadi pada masa lalu (sejarah). Proses ini membutuhkan pencarian bukti-bukti (data), mengumpulkan dan mengorganisasikannya, mengevaluasinya dan mengonstruksikannya secara naratif dari bukti-bukti yang holistik dan dapat dipercaya. Pengumpulan data kesejarahan dapat berupa data arsip, sejarah lisan, naskah, peta, foto, dan lain-lain. Wawancara dan pengamatan lapangan dilakukan untuk melengkapi data arsip. Analisis diakronik dan sinkronik dilakukan untuk mendapatkan gambaran perubahan lingkungan dan pengaruhnya pada arsitektur istana.

\section{Hasil dan Pembahasan}

\section{Perpindahan ke Lintasan Sungai Induk (Sungai Kapuas) Sebagai Jalur Utama Perdagangan di Kalimantan Barat}

Anthony Reid (2011) menyebutkan kelompok masyarakat berbahasa Austronesia sebagai bangsa perintis yang merajut kepulauan di Asia Tenggara kedalam jaringan perdagangan global, yang diidentifikasikan oleh Denys Lombard (2005) sebagai orang-orang laut. Akan tetapi pada abat XVII, masyarakat nusantara dengan budaya maritimnya yang kental mengalami kemunduran. Berkembangnya paham merkantilisme pada abad ke-16 dan 17 di Eropa menghasilkan monopoli perdagangan dan pelayaran. Merkantilisme sebagai suatu kebijaksanaan politik ekonomi dari negaranegara imperialis bertujuan untuk mengumpulkan sebanyak-banyaknya kekayaan. Merkantilisme telah memberikan kekuatan yang luar biasa bagi setiap negara kolonialis untuk memfokuskan segala kegiatan perdagangan dalam rangka memperoleh kekayaan yang banyak dan kekuasaan yang luas. Meskipun tidak mematikan perdagangan namun sangat membatasi ruang gerak kapal-kapal pelaut Indonesia. Gambaran perdagangan Asia Tenggara pada saat itu sebenarnya menempatkan rempahrempah pada mata dagangan skala kecil, justru bahan makanan seperti beras, garam, dan asinan (ikan asin), tuak, tekstil dan barang logam yang lebih dominan.

Jaringan perdagangan di kawasan Asia Tenggara menggunakan jalur utama melalui laut dan sungai, jalur darat sangat jarang ditemukan. Jalur darat mempunyai hutan yang sangat lebat, curah hujan yang tinggi dan sulit dipelihara. Jalur yang melintasi Semenanjung Malaka antara Pantai Benggala dan Teluk Thailand sangat penting untuk perdagangan jarak jauh. Beberapa jalur darat melalui Siam, Kedah, Patani, Vietnam bagian utara, dan Laos juga merupakan jalur yang paling banyak dikunjungi selama zaman perdagangan. Namun banyak pedagang tetap memilih jalur laut, walaupun jauh dan lama, untuk menghindari siapa saja yang mendominasi wilayah-wilayah yang dilalui (Reid, 2011). Jalur jaringan perdagangan di Asia tenggara pada abad 15 sebelum terjadinya ledakan pasar pada abad 16 dapat dilihat pada gambar dibawah. 


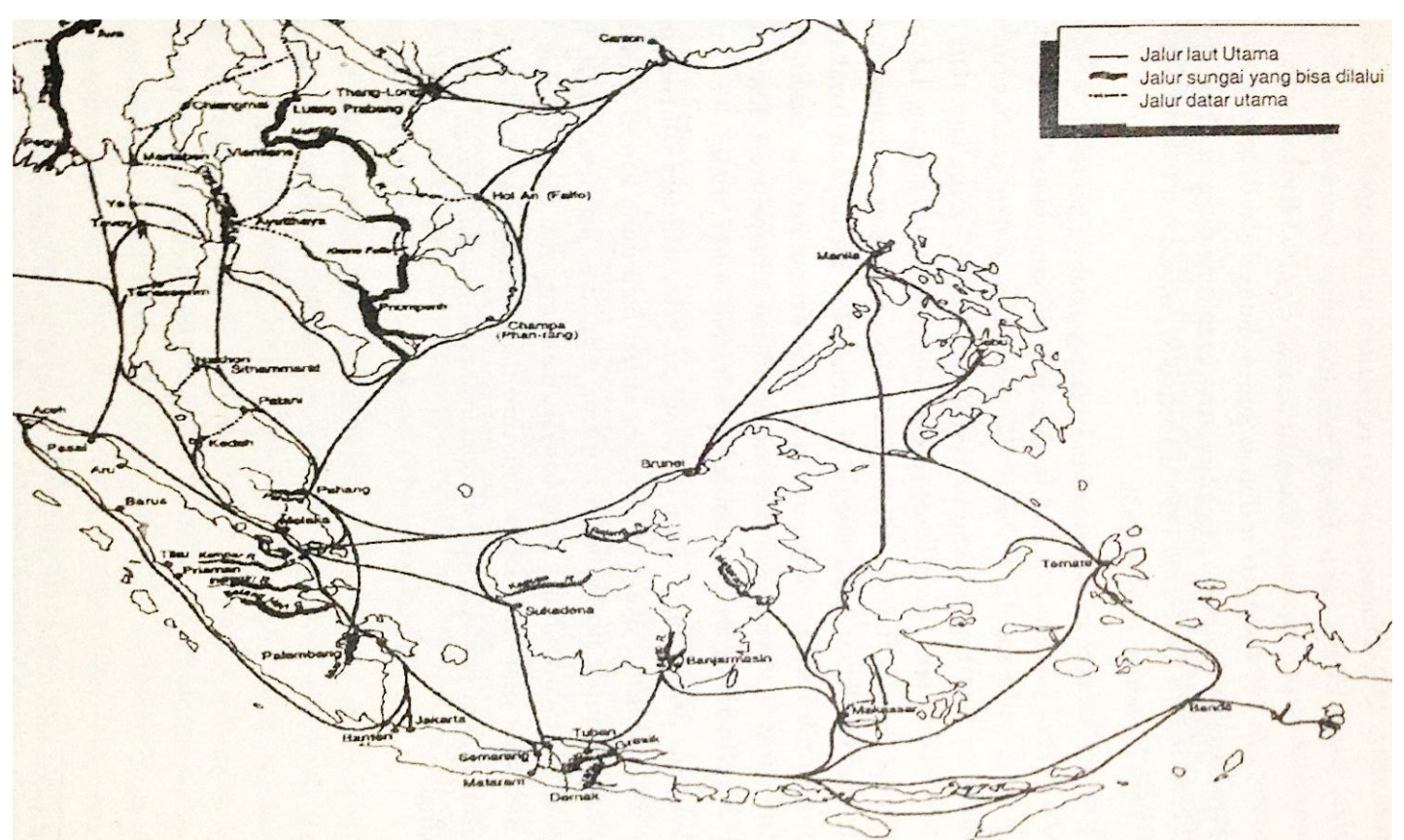

Gambar1. Jaringan Perdagangan Dia Asia Tenggara Pada Abad 15

Sumber: (Reid, 2011)

Di Kalimantan Barat (West Borneo) jalur utama perdagangan antar wilayah menggunakan jalur Sungai Kapuas yang membelah wilayah Kalimantan Barat hingga pedalaman. Dimulai pada abad ke 16, seiring dengan berkembangnya kesultanan Islam di Kalimantan Barat, menjadi awal munculnya jaringan perdagangan dan kota-kota pelabuhan. Kesultanan Sukadana yang berada di pesisir barat laut Kalimantan menjadi kota pelabuhan pertama di Kalimantan Barat ditandai dengan berdirinya kantor dagang Belanda (VOC) pada tahun 1605 M. Tahun 1786 M Kesultanan Pontianak dengan dibantu oleh VOC mengembangkan pelabuhan baru dengan orientasi perdagangan regional dan global ke arah pedalaman wilayah-wilayah kesultanan melalui jalur utama Sungai Kapuas.

Meskipun Sungai Kapuas menjadi jalur masuk utama untuk perdagangan namun lokasi kerajaan-kerajaan Melayu pada saat itu masih banyak yang berada di jalur sungai-sungai kecil (anak Sungai Kapuas), hulu sungai hingga pedalaman, seperti Kerajaan Matan di hulu Sungai Pawan, Kerajaan Sanggau di Labai Lawai (hulu Sungai Sekayam), Kerajaan Sekadau di daerah Belitang (hilir Sungai Rawak), Kerajaan Landak di Ningrat Batur (hulu Sungai Landak), dan Kerajaan Sambas di Paloh serta beberapa kerajaan di hulu Sungai Kapuas (Kerajaan Selimbau, Piasak, Nanga Silat, Semitau, Suhaid, Jongkong dan Nanga Bunut). Dengan meningkatnya volume perdagangan dan kebutuhan yang majemuk menjadikan jalur perdagangan Sungai Kapuas menjadi ramai dan sibuk. Beberapa kesultanan kemudian memindahkan pusat pemerintahannya ke wilayah yang berhubungan langsung dengan jalur perdagangan dan pelayaran (pesisir Kalimantan dan jalur utama Sungai Kapuas) dengan salah satu pertimbangan kedekatan jalur transportasi untuk perdagangan. Seperti Kesultanan Matan yang kembali pindah ke muara Sungai Pawan, Kesultanan Sanggau dan Sekadau ke Sungai Kapuas, Kesultanan Landak ke Sungai Landak Besar hingga berdirinya Kesultanan Pontianak di muara (hilir) Sungai Kapuas.

\section{Sistem Perdagangan Global dan Pembentukan Wilayah Kesultanan-kesultanan Melayu di Kalimantan Barat}

Pelayaran berdasarkan musim mengakibatkan berkembangnya wilayah-wilayah pelabuhan dimana para pedagang menunggu pergantian musim untuk kemudian kembali ke asalnya. Dilain sisi memberikan kesempatan aktivitas perdagangan lokal yang memberikan pasokan ke kota pelabuhan 
dengan bahan makanan, bahan bangunan, dan barang dagangan lokal lainnya dan sebaliknya mereka mengumpulkan barang-barang impor (logam, tekstil).

Saat Singapura diberlakukan sebagai pelabuhan bebas internasional, Pontianak menjadi poros terdepan Hindia Belanda dalam menarik sebagian perdagangan luar negeri. Pada 1834 pemerintah Hindia Belanda memberlakukan Pontianak dan Sambas sebagai pelabuhan bebas, oleh karena itu kapal niaga asing bebas untuk masuk walaupun dengan peraturan pelayaran dan perdagangan yang ketat dan tarif pajak ekspor impor yang tinggi (Dick and Rimmer, 1998). Barang-barang yang datang melintasi lautan di Pontianak, oleh orang-orang Cina dan Bugis yang tinggal di Pontianak dikirim lagi ke ibukota-ibukota kerajaan di pedalaman, dimana barang-barang tersebut dijual kepada raja-raja dan pedagang di pedalaman atau ditukar dengan hasil-hasil dari daerah pedalaman. Raja-raja menjual barang-barang berasal dari Pontianak, seperti garam, tembakau, kain hitam, besi dan lain-lain kepada orang-orang Dayak dengan harga tinggi yang dibayar dengan beras atau hasil kerajinan tangan sehingga terkesan semacam pajak daripada perdagangan (Veth, 1854). Para pedagang Melayu dan Bugis, yang bermukim di daerah pedalaman, dapat melangsungkan perdagangan barter dengan orang-orang Dayak sejauh yang diizinkan raja-raja. Barang-barang tersebut kemudian dikirim ke Pontianak. Untuk perdagangan luar negeri, sepenuhnya dilakukan dengan menggunakan kapal-kapal Pontianak.

Jenis perdagangan di Pontianak dapat dibedakan menjadi dua golongan yaitu perdagangan dalam negeri dan luar negeri. Perdagangan dalam negeri sebagian berlangsung dengan tempat-tempat disepanjang pantai barat dan sebagian lagi dengan tempat-tempat di sepanjang Sungai Kapuas dan cabang-cabangnya. Namun banyak raja/sultan yang berkuasa bertindak melakukan pemerasan, kekerasan dan pengkhianatan sehingga jalannya perdagangan menjadi terhambat (Veth, 1854; Linblad, 2012). Untuk mengatasi permasalahan tersebut, pada tahun 1847 ditandatangani kontrakkontrak antara pemerintah Belanda dengan raja-raja untuk menjadikan keadaan lebih baik. Upayaupaya samar pada dasarnya untuk membangkitkan monopoli perdagangan luar negeri oleh pemerintah Belanda. Namun terjadi benturan-benturan kepentingan antara pedagang Eropa dengan Cina di sepanjang pantai dan luar negeri, dan orang Cina dengan Melayu di sepanjang sungai.

Pada tahun 1880, pola berlapis pada sistem perdagangan di wilayah Kalimantan terbentuk berdasarkan pelaku perdagangan yang dibedakan oleh etnis (Linblad, 2012). Melayu atau Banjar terlibat khusus dalam perdagangan sungai yang dekat dengan kontak langsung dengan orang Dayak. Orang Cina masuk perdagangan sungai dalam hubungannya dengan pengiriman jarak jauh. Orang Cina menguasai pasar bahan pokok regional dan jalur perdagangan ke Singapura. Orang-orang Eropa khusus dalam perdagangan luar negeri, baik dengan pedagang asing dan intra Indonesia, dan jarang muncul di pasar kecil sepanjang sungai. Orang Bugis, Cina atau Eropa berkonsentrasi pada perdagangan dengan dunia luar. Mereka tidak mudah melakukan hubungan perdagangan dengan pedagang Melayu yang umumnya berlayar sampai ke cabang-cabang anak sungai dengan kecepatan sangat lambat dan memahami transaksi bisu dengan orang Dayak. Jenis perdagangan dibagi menjadi 3 kategori yaitu perdagangan lokal, regional dan global/internasional. Perdagangan lokal dapat dilakukan oleh pribumi (Melayu dan Dayak), perdagangan regional oleh orang Cina, Bugis dan Melayu dan perdagangan global/internasional hanya dapat dilakukan oleh orang Cina (melalui kerjasama perdagangan) dan orang-orang Belanda (Eropa). 


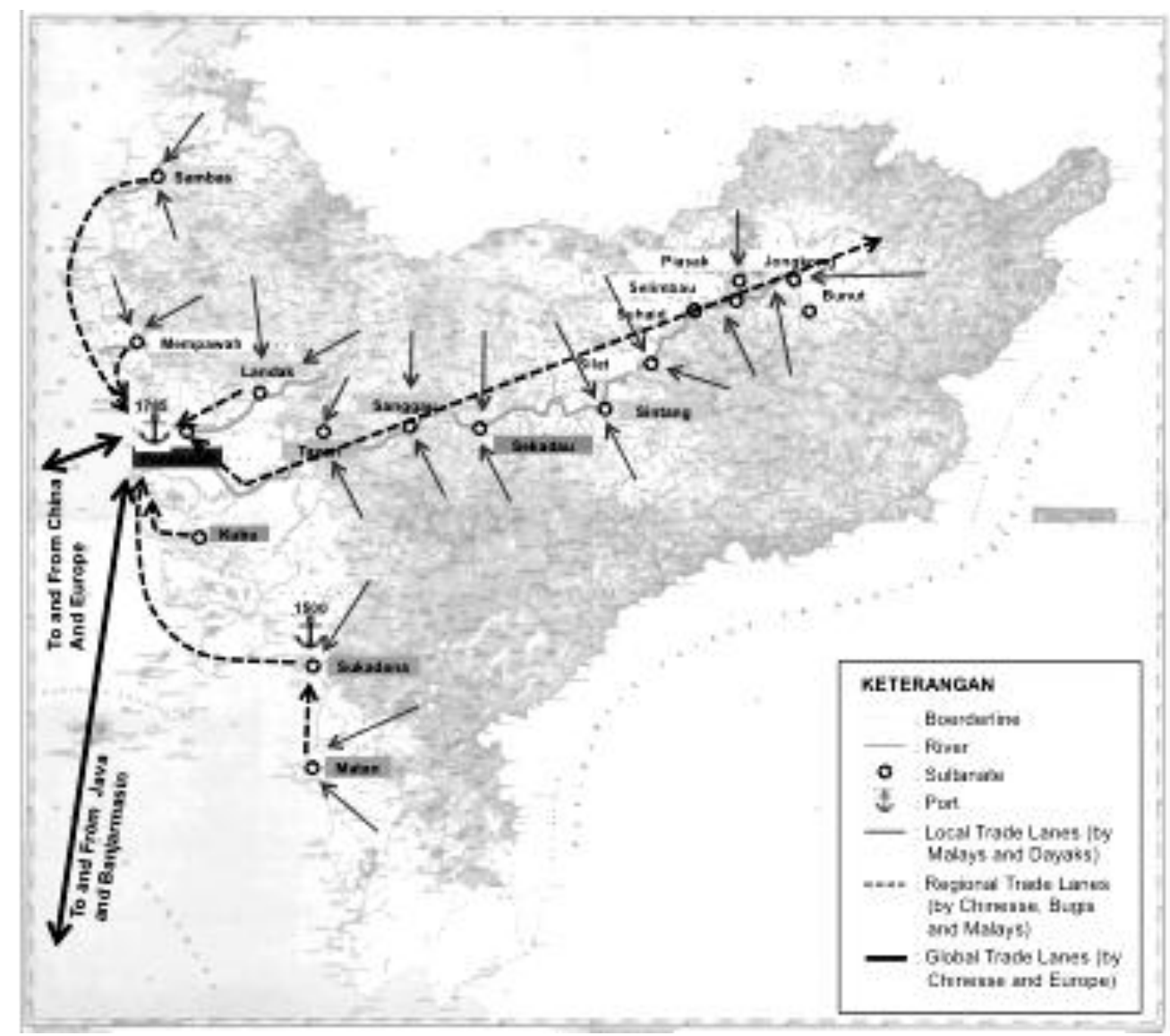

Gambar 2. Sistem dan Jaringan Perdagangan di Wilayah Borneo Barat Sumber: Veth, 1854; Lontaan, 1975; Linblad, 2012; Andi, 2016

Para pedagang Cina merebut kendali atas ekspor tradisional dari orang Bugis dan Melayu. Keberhasilan Cina berasal dari kohesi internal mereka yang luar biasa dan kesetiaan yang berkombinasi dengan kemauan yang lebih besar untuk melakukan perbaikan dalam teknik berlayar. Selain itu, orang Cina lebih disukai oleh penguasaan kolonial karena mereka tidak mendukung setiap kebangkitan Islam. Peran Cina di perdagangan menyebar dengan cepat di seluruh wilayah, menghubungkan sejumlah pasar lokal untuk masuk ke pasar utama internasional di Singapura. Meskipun sering terjadi persaingan antara Cina dan Eropa dalam perdagangan luar negeri namun seringkali berakhir dengan damai atau bahkan dalam bentuk kerjasama, misalnya pedagang Cina bekerja secara simultan untuk dirinya sendiri dan sebagai agen dari Borsumij (salah satu perusahaan dagang Belanda).

Dalam sistem perdagangan, pemerintah Hindia Belanda sangat mempercayai masyarakat etnis Cina bahkan dalam setiap wilayah (Afdeeling) bentukannya ditempatkan wilayah khusus untuk para pedagang Cina (Chinesse Camp) yang letaknya menjadi satu kesatuan wilayah dengan kompleks istana, controleur Belanda dan pelabuhan/dermaga. Pola spasial pusat kota kesultanan-kesultanan Melayu di Kalimantan Barat dapat dilihat pada Gambar.3. 


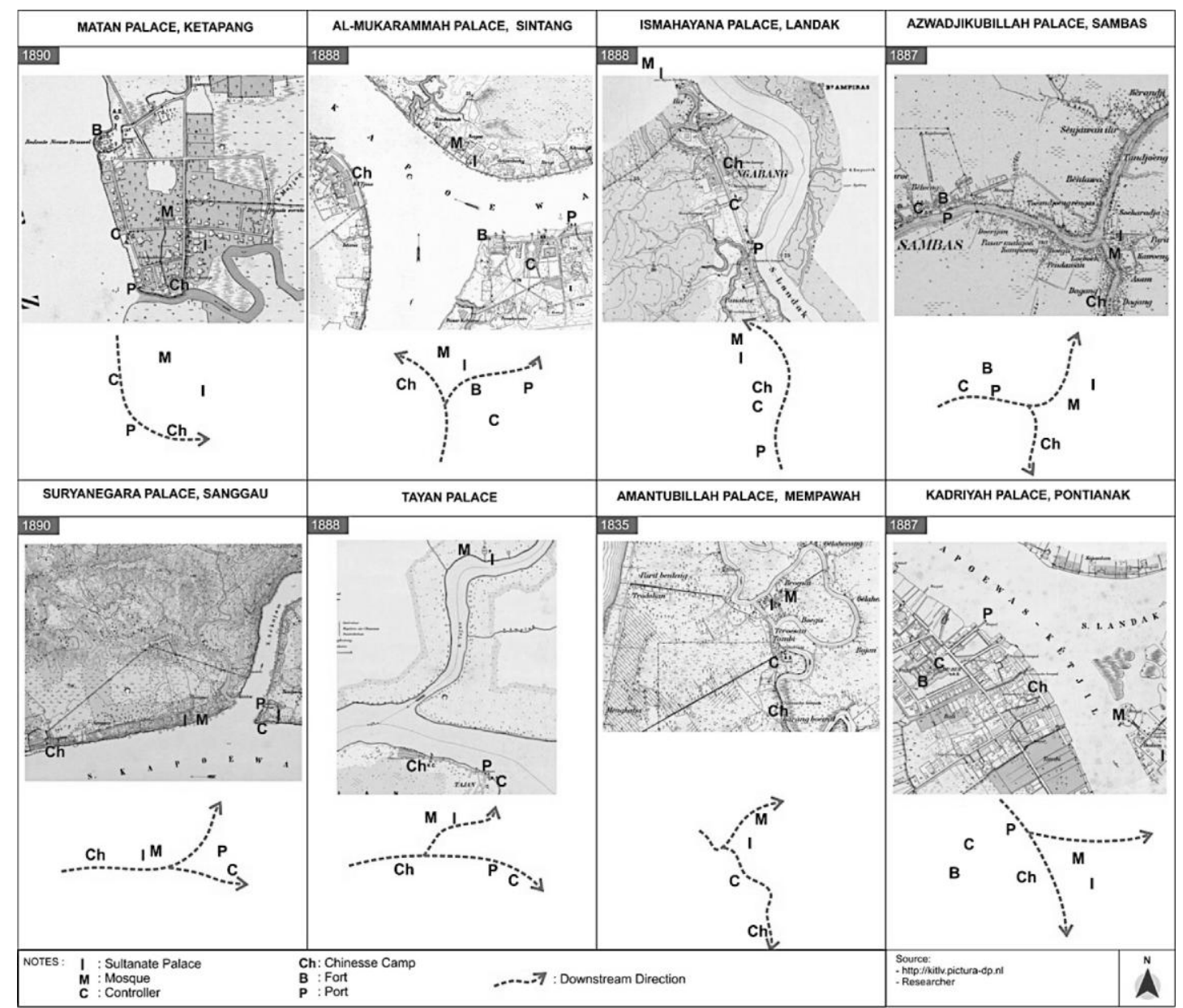

Gambar 3. Pola Spasial Pusat Pemerintahan Kesultanan Pada Masa Kolonial Sumber: kitlv.pictura-dp.nl diakses 13 Feb 2013; Andi, 2016

Akhir abad XIX, permukiman sekitar wilayah kota-kota kesultanan semakin bertambah. Pada Kesultanan Pontianak, permukiman baru didirikan di tanah milik kesultanan dan penempatannya ditentukan oleh sultan yang disesuaikan status sosial ekonomi, kekuasaan dalam pemerintahan, kelompok etnis, serta keahlian dan mata pencaharian yang diusahakannya. Permukiman baru di Pontianak bagian timur bertambah, selain Kampung Tambelan, berdiri pula Kampung Serasan, Kampung Banjar, Kampung Kapur dan Kampung Tanjung (Usman, 2011). Para pendatang yang bermata pencaharian pedagang ditempatkan di bagian timur sisi selatan Sungai Kapuas Kecil. Selain Kampung Kamboja dan Mendawai, berdiri pula Kampung Tambi, Kampung Arab, Kampung Melayu, Kampung Kuantan, Kampung Syekh Ahmad dan Kampung Bangsir (Bansir).

\section{Struktur Ruang Wilayah Hulu-Hilir dan Banyak Pusat}

Struktur ruang wilayah kesultanan-kesultanan Melayu di Kalimantan Barat dipengaruhi oleh sistem hulu-hilir aliran Sungai Kapuas sebagai sungai yang membelah wilayah Kalimantan Barat sampai ke pedalaman. Sistem hulu-hilir ini mengacu pada sistem perdagangan domestik dan global yang berlaku di wilayah kesultanan. Kesultanan-kesultanan terletak pada daerah aliran sungai (riparian) mulai dari hulu ke hilir. Kesultanan-kesultanan yang berada di hilir mengumpulkan komoditas di pedalaman dan mengirimkan pasokan ke kesultanan di hulu melalui jalur sungai untuk kemudian dipertukarkan dengan komoditas lainnya dari luar pulau. Komoditas dari luar pulau kemudian dibawa ke pedalaman untuk dipertukarkan lagi dengan komoditas pedalaman. Sistem ini berlaku sejak aktivitas perdagangan diberlakukan hingga berakhirnya kesultanan. 
Kerajaan-kerajaan yang awalnya berada di anak sungai kemudian memindahkan pusat kesultanannya pada jalur perdagangan utama sepanjang tepian Sungai Kapuas. Letak-letak strategis dan menguntungkan menjadi pilihan kesultanan seperti pada persimpangan antara dua sungai pedalaman (Kerajaan Sintang), muara (hulu) sungai (Sambas, Matan dan Mempawah), pesisir (Sukadana/Tanjungpura) serta akses-akses ke komoditas unggulan seperti Kerajaan Landak yang terletak di Sungai Landak dekat dengan akses komoditas tambang intan. Kesultanan-kesultanan yang berada di muara (hulu) kemudian menjadi lokasi pengumpulan komoditas seperti Kesultanan Sukadana, Sambas dan Pontianak. Kesultanan-kesultanan lainnya berada di bagian tengah dan pedalaman dengan akses langsung ke kesultanan-kesultanan hulu, seperti pada Gambar 4.

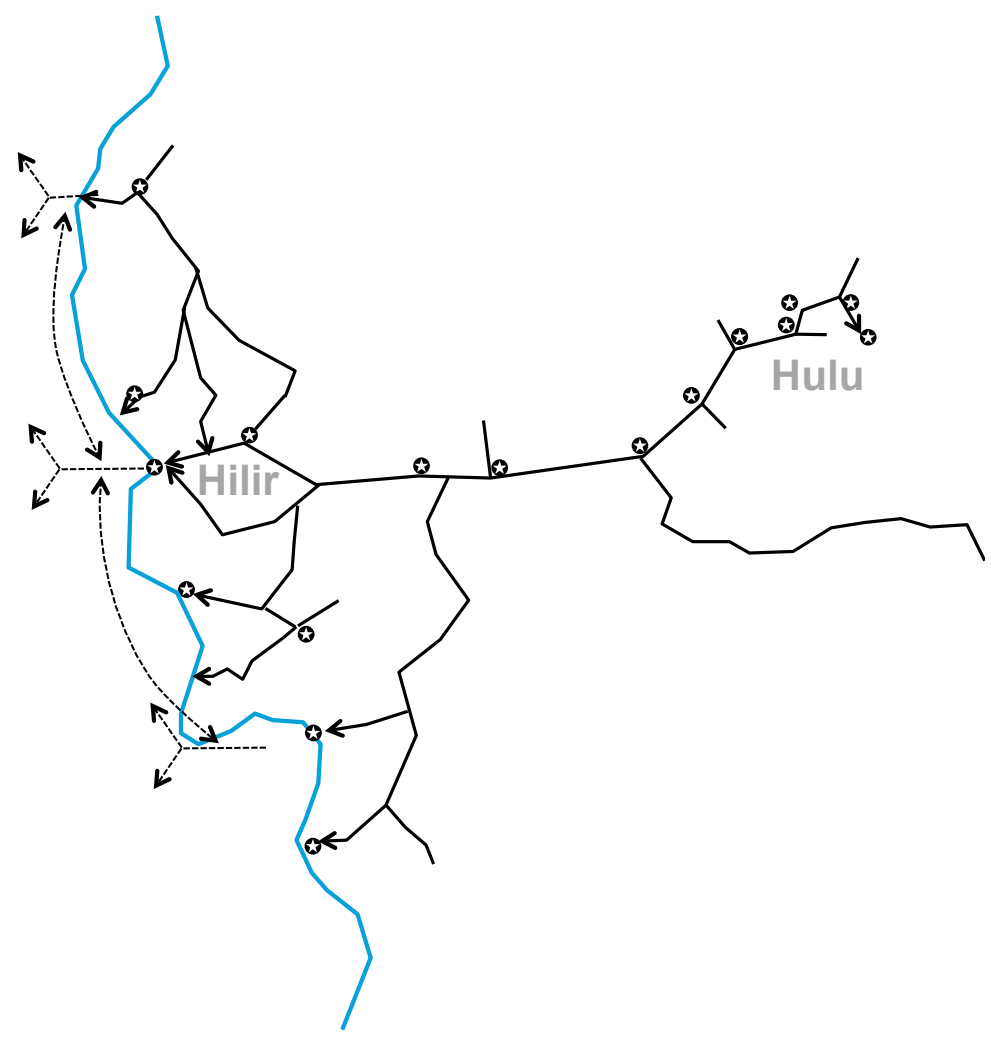
Gambar 4. Sistem Hulu-Hilir Pada Struktur Ruang Wilayah Kesultanan-kesultanan Melayu Kalimantan Barat
Sumber: Analisis, 2017

Sistem hulu-hilir awalnya berjalan secara inkremental dan natural dengan banyak pusat tanpa inti sistem. Bronson (dalam Manguin, 2014) mengungkapkan bahwa pusat-pusat pada daerah aliran sungai dipandang sebagai sistem-sistem lepas yang bersaing memperebutkan andil dalam jaringan yang sama. Masing-masing kerajaan/kesultanan menjadi pusat pengumpulan, penyebaran dan pertukaran komoditas di wilayahnya. Hubungan kesultanan hilir dan hulu menjadi terkoneksi dan saling ketergantungan dalam jaringan yang sama. Struktur antar kesultanan membentuk struktur ruang yang linier bercabang dengan banyak pusat. Namun semenjak ada upaya monopoli perdagangan oleh VOC, yang dilanjutkan oleh pemerintah kolonial Belanda, mulai diterapkan inti sistem dengan pemusatan distribusi pada satu kesultanan yang berada di hilir Sungai Kapuas yaitu Kesultanan Pontianak. Letak kesultanan Sintang yang strategis juga menjadi incaran untuk dijadikan sebagai inti (pusat) di pedalaman namun akibat gagal akibat perlawanan setempat. Pada periode pemerintahan kolonial, sistem hulu-hilir berkembang dengan pemusatan pada wilayah hilir yaitu wilayah Kesultanan Pontianak. Sistem hulu-hilir ini menjadi dasar pembentukan wilayah residen 
Borneo's Westeer-Afdelling yang menempatkan pusat residen di wilayah Kesultanan Pontianak yang berada di hilir dengan kesultanan-kesultanan lainnya berada di bawah residen di Pontianak.

\section{Konfigurasi Spasial Pusat Wilayah Kesultanan Yang Terbatas dengan Pinggiran Yang Melebar}

Pusat ibukota kesultanan-kesultanan Melayu di Kalimantan Barat berada di tepian sungai atau pesisir dan berbatasan langsung dengan air. Pengembangan pusat kesultanan cenderung melebar sepanjang tepian sungai, sebelum dan sesudah lokasi pusat ibukota kesultanan. Manguin (2014) menyebut daerah pengembangan pusat-pusat politik yang berada di sepanjang tepian sungai sebagai wilayah pinggiran (umland) bukan pedalaman (hinterland), karena tidak terletak di belakang (daratan). Pengembangan ke arah daratan menjadi terbatas karena terkendala jalur pergerakan yang berupa semak dan hutan lebat dengan kondisi tanah berawa serta gambut. Konfigurasi spasial istana kesultanan Melayu di Kalimantan Barat sejak periodepemerintahan kesultanan berkembang sepanjang tepian sungai, melebar mengikutialur sungai. Konfigurasi spasial istana-istana terdiri atas 4 pola, yaitu: 1) Pola linier,konfigurasi spasial melebar mengikuti garis sempadan sungai; 2) Pola linierenclosure, konfigurasi spasial melebar mengikuti garis sempadan sungai danmengelompok pada satu kawasan membentuk ruang; 3) Pola aksial, konfigurasispasial membentuk garis sumbu/aksis, dan 4) Pola sporadis, konfigurasi spasialyang berkembang secara tidak teratur (Gambar $5)$.

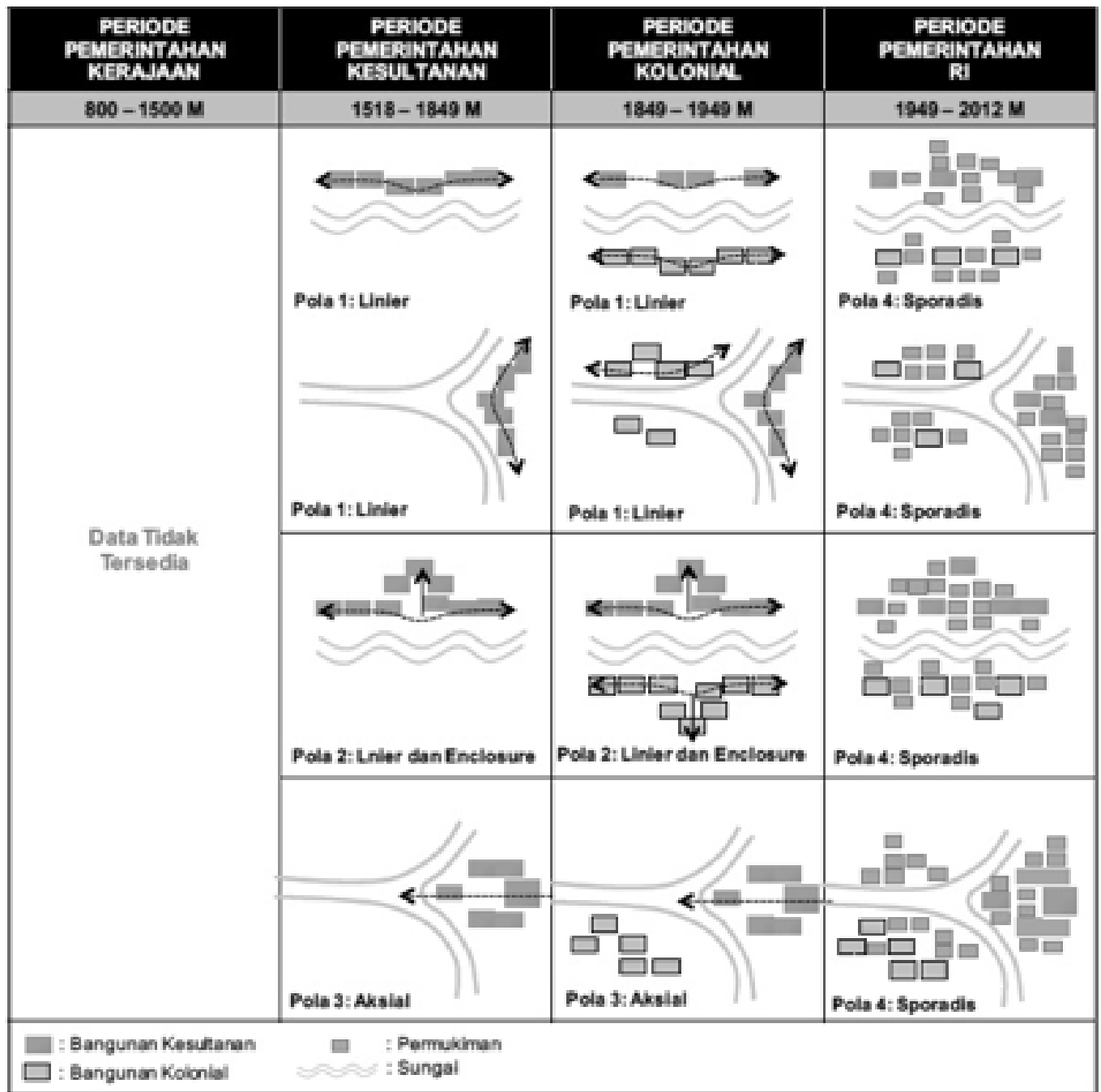

Gambar 5. Konfigurasi Spasial Wilayah Pusat Kesultanan-kesultanan Melayu di Kalimantan Barat Sumber: Andi, 2016 
Konfigurasi spasial Pola 1: linier, yaitu konfigurasi bangunan yang tersusun secaralinier mengikuti jalur dan sempadan tepian sungai. Konfigurasi ini terbentuk olehpengaruh kondisi geografis kawasan, fungsi dan orientasi sungai, sungai sebagaijalur perdagangan, dan kelengkapan sistem kesultanan. Istana kesultanan terletakpada kawasan tepian sungai dengan kondisi geografis berkelok-kelok (meander)mengikuti jalur sungai yang terbentuk akibat arus air sungai. Pengembangannyamelebar sepanjang tepian sungai, karena wilayah daratan masih berupa hutan lebatdan minim akses. Pola linier ini dapat terbentuk pada jalur badan sungai ataupun persimpangan sungai. Posisi istana sebagai pusat kesultanan pada konfigurasi tidakselalu berada di tengah kawasan dan menjadi orientasi kawasan. Karena orientasiseluruh bangunan ke arah sungai, semua bangunan mempunyai akses langsung kesungai. Sungai berfungsi sebagai sumber kehidupan dan jalur transportasi utamayang sangat penting bagi kehidupan kesultanan.

Konfigurasi spasial Pola 2: konfigurasi linier dan eclosure, pola ini hampir sama dengan pola konfigurasi spasial linier, perbedaannya hanya pada kelengkapan sistem pemerintahan kesultanan yang lebih banyak, sehingga pada pusat kawasan terjadi pengelompokan bangunan yang membentuk ruang-ruang terbuka, namun tetap dengan orientasi kes sungai, seperti pada kawasan istana kesultanan Matan, Sanggau, dan Mempawah. Konfigurasi spasial bangunan-bangunan perwakilanpemerintahan kolonial juga mempunyai kelengkapan yang berbeda sesuai dengan status perwakilan (residen, asisten residen, atau kontrolir) yang disandangnya. Konfigurasi spasial Pola 3: konfigurasi aksial, yaitu konfigurasi spasial yang terbentuk di sekitar poros atau sumbu yang tegak lurus dengan bangunan monumental (bangunan istana kesultanan), seperti pada kawasan istana kesultananPontianak dan Sambas. Konfigurasi spasial ini dipengaruhi oleh posisi kesultanan yang kuat dalam sistem pemerintahan dan perekonomian, sehingga kesultanan dapat memiliki bangunan istana yang besar dan perlu menata lingkungan istananya. Kesultanan Pontianak dan Sambas berkembang pesat karena letaknya pada wilayah hilir sungai dan pada persimpangan sungai yang mengarah ke pedalaman, sehingga memperoleh pendapatan dari pajak yang cukup besar.

Konfigurasi spasial Pola 4: konfigurasi sporadis, yaitu konfigurasi spasial yangberkembang tanpa pola dan tidak beraturan, spontan dan liar mengikuti jalur sirkulasi dan tata letak bangunan yang sudah ada sebelumnya. Konfigurasi spasial ini terbentuk akibat hilangnya fungsi dan kekuasaan kesultanan, intrusi permukiman pada kawasan kesultanan dan pembangunan jalan darat. Pada masa pemerintahan RI, kekuasaan kesultanan secara politik dan kewilayahan telah hilang sehingga bangunan istana hanya menjadi objek wisata dan kesultanan tidak memiliki wewenang untuk mengatur wilayah-wilayah di luar kawasan istana,sehingga pembangunan oleh masyarakat tidak dapat dihindari. Beberapa lahan milik kerabat kesultanan juga dijual kepada masyarakat umum sehingga wilayah bagian dalam istana juga dapat dihuni oleh masyarakat. Pada kawasan istana kesultanan Pontianak telah berdiri bangunan-bangunan milik masyarakat di dalam batas pagar istana. Konfigurasi sporadis ini juga dipengaruhi oleh pembangunan jalan darat dan pengembangan wilayah ke daratan yang menyebabkan fokus pembangunan wilayah ke arah daratan dan membiarkan kawasan tepian sungai berkembang secara sporadis.

Sungai menjadi faktor penting dalam pengembangan ruang pusat kesultanan. Sungai menjadi sumber kehidupan dan jalur transportasi utama dari hulu ke hilir. Sungai menjadi penghubung antar pusat-pusat kesultanan dalam hal komunikasi dan pertukaran barang (perdagangan). Karakter kesultanan Melayu yang hidup dari kegiatan perdagangan semakin menguatkan keberadaan sungai sebagai orientasi utama kesultanan. Kegiatan agraris cenderung dilakukan oleh masyarakat pedalaman (Dayak) yang kemudian menukarkan hasil ladangnya dengan komoditas dari luar di wilayah kesultanan seperti tekstil dan garam. Untuk memenuhi kebutuhan, kesultanan-kesultanan seringkali mengimpor barang dari luar pulau untuk kemudian dipertukarkan dengan komoditas hasil tambang (emas, intan) dan kebun (lada, karet). Keterbatasan pengembangan arah daratan dan aktifnya daerah sepanjang tepian sungai menyebabkan pengembangan pusat-pusat kesultanan tidak pada pusat kesultanan melainkan melebar sepanjang wilayah pinggirannya (Gambar 6). 


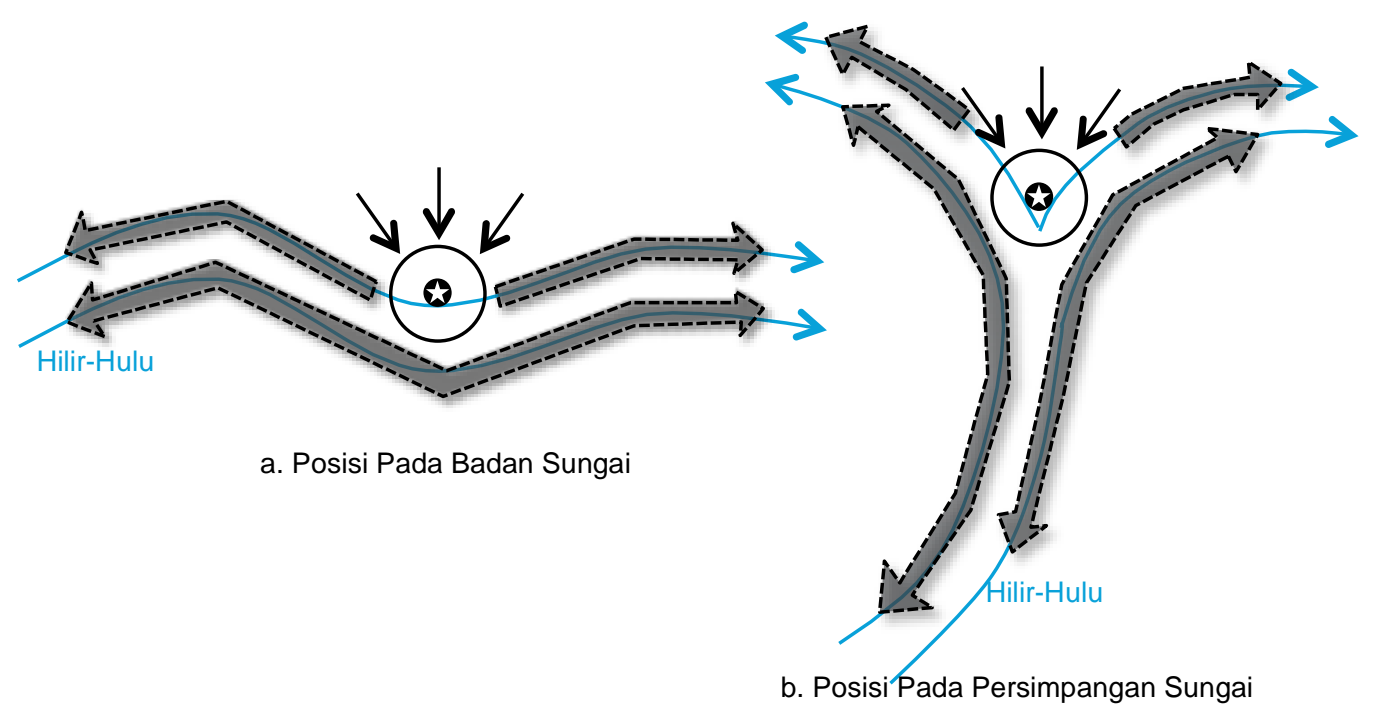

Gambar 6. Pola Pengembangan Pusat-pusat Kesultanan Melayu di Kalimantan Barat Pada Daerah Tepian Sungai

Sumber: Analisis, 2017

Orientasi kawasan dan bangunan istana kesultanan umumnya ke arah sungai, kecuali kesultanan Mempawah yang berorientasi ke daratan dan jauh dari sungai. Hal ini dikarenakan sejarah awal berdirinya kerajaan Mempawah merupakan kerajaan suku Dayak yang berada di bukit Sidiniang. Kerajaan ini akhirnya tunduk pada Kesultanan Matan dan menjadi Kesultanan Mempawah dibawah pimpinan Opu Daeng Manambon. Kesultanan Mempawah juga seringkali diserang oleh pihak kolonial Belanda yang dibantu Kesultanan Pontianak melalui jalur sungai sehingga kesultanan seringkali berpindah menghindari serangan musuh.

Kesultanan-kesultanan Melayu di Kalimantan Barat tidak mempunyai orientasi kosmologis seperti umumnya kerajaan/kesultanan di Jawa yang pengembangan pusat kerajaannya didasarkan pada pola mandala akibat pengaruh ajaran Hindu-Budha. Meskipun ajaran Hindu-Budha pernah berlaku pada masa kerajaan namun pada saat kerajaan menjadi kesultanan (Islam) maka ajaran Islam yang lebih utama. Didalam Islam tidak terdapat orientasi kosmologis untuk penempatan ruang wilayah kesultanan seperti halnya ajaran Hindu-Budha. Kitab-kitab dan naskah pedoman bagi rajaraja Islam (kitab Hikayat Raja-raja Pasai, Taj us-Salatin, Al Mahawib) lebih mengutamakan pedoman dan posisi raja/sultan di dalam kesultanan. Orientasi kesultanan-kesultanan Melayu lebih dipengaruhi oleh kondisi geografis dan aktivitas perdagangan serta komunikasi yang berlangsung dominan di sepanjang tepian sungai.

\section{Kesimpulan}

Struktur wilayah kesultanan-kesultanan Melayu di Kalimantan menggunakan sistem hulu-hilir dengan banyak pusat kesultanan pada setiap wilayah hulu dan hilir. Setiap kesultanan dihubungkan oleh jaringan yang sama yaitu sungai Kapuas sebagai sarana transportasi dan komunikasi. Hubungan antar kesultanan hulu dan hilir saling membutuhkan. Kesultanan hulu mengumpulkan komoditaskomoditas pedalaman (emas, intan, lada, karet, damar, rotan) untuk dipertukarkan dan diperjualbelikan di wilayah kesultanan hilir dengan komoditas dari luar pulau dan global (garam, tekstil, tembakau dan candu). Pada periode pemerintahan kolonial, kesultanan hilir (Kesultanan Pontianak) dijadikan sebagai pusat distribusi dan pengumpulan komoditas. Wilayah-wilayah kesultanan kemudian digabung menjadi residen Borneo's Westeer-Afdelling (Borneo Barat) dengan mengacu pada sistem hulu-hilir dan menempatkan wilayah Kesultanan Pontianak (hilir) sebagai ibukota residen. 
Wilayah-wilayah pusat kota kesultanan Melayu di Kalimantan Barat sangat dipengaruhi oleh kegiatan perdagangan global baik oleh kebijakan perdagangan dan keamanan Hindia Belanda (penempatan fungsi wilayah) juga akibat kegiatan perdagangan lokal dan regional yang tumbuh dengan cepat dengan munculnya kelompok pedagang, permukiman, pasar, dan lain-lain yang tidak teratur yang mendekatkan diri dengan pusat kekuasaan/kegiatan. Dasar perdagangan dan ekonomi menyebabkan kota tumbuh linier organik sepanjang tepian sungai sebagai jalur transportasi utama. Perkembangan wilayah kota kesultanan juga mengelompok sekitar pusat aktivitas kesultanan (istana) dan perdagangan (pelabuhan dan pasar). Pengaruh politik masa kolonial menempatkan istana sebagai pusat kekuasaan lokal dan controleur Belanda sebagai kantor perwakilan kolonial Belanda menjadi satu kesatuan wilayah.Istana kesultanan Melayu di Kalimantan Barat tidak mempunyai orientasi dan hierarki kosmologis dikarenakan pembentukan wilayah kesultanan sifatnya sangat pragmatis yang dipengaruhi oleh sistem perdagangan global/regional dan aksesibilitas pada sungai. Perkembangan pusat kesultanan pada area daratan sangat terbatas. Perkembangan cenderung melebar sepanjang daerah aliran sungai.

\section{Daftar Pustaka}

. Tanpa Tahun. Sejarah Kerajaan TanjungpuraMatan. Tanpa Penerbit.

Andi, Uray Fery. (2016): Sejarah Perkembangan Arsitektur Istana Kesultanan Melayu di Kalimantan Barat, Disertasi Doktor Arsitektur, Institut Teknologi Bandung, Bandung

Barnet, Jonathan. (1974): Urban design as public policy: Practical methods for improving cities, Architectural Record Books

Collins, J. T. (2001). Contesting Straits-Malayness: The Fact of Borneo. Journal of Southeast Asian Studies,32(3), 385-395.

Coedes, George. (2010). Asia Tenggara Masa HinduBuddha, Pusat Penelitian dan Pengembangan Arkeologi Nasional, Jakarta

Damayanti, R., dan Handinoto. (2005). Kawasan "pusat kota" dalam perkembangan sejarah perkotaan di Jawa.Dimensi Teknik Arsitektur, 33 (1),34 - 42.

De Graaf, H.J. \& Pigeaud, T.H. (1989). Kerajaan Islam Pertama di Jawa: Tinjauan Sejarah Politik Abad XV dan XVI. Jakarta: Pustaka Utama Grafiti dan KITLV.

Dick, HW \& Rimmer, PJ, 1998: Beyond the third world city: the new urban geography of South-east Asia', Urban Studies, vol. 35, no. 12,

Enthoven, J. J. . (2013)Sejarah dan Geografi Daerah Sungai Kapuas Kalimantan Barat, Terjemahan Bijdragen Tot De Geographie van Borneo's Wester-Afdeeling 1905. (P. O. C. Yeri, Ed.) (1st ed.), Pontianak, Institut Dayakologi.

Groat, L., \& Wang, D. (2002). Architectural Research Method. Canada: John Wiley and Sons, Inc.

Lindblad, J. T. (2012). Antara Dayak dan Belanda, Sejarah Ekonomi Kalimantan Timur dan Kalimantan Selatan 1880-1942 (1st ed.). Jakarta: KITLV-Jakarta.

Leur, J. C. van. (1967). Indonesia Trade and Society:
Essays in Asian Social and Economic History, The Hague, The Hague: W. Van Hoeve Publishers.

Lombard, D. (2005). Nusa Jawa Silang Budaya, - Buku I, II, \& III. Jakarta: Gramedia Pustaka Utama.

Lontaan, J.U. (1975). Sejarah, Hukum Adat, dan Adat Istiadat Kalimantan-Barat. Pontianak: Pilindo.

Manguin, P. (2014). Sifat Amorf Politi-politi Pesisir Asia Tenggara Kepulauan. In P. Manguin (Ed.), Kedatuan Sriwijaya (Kedua, p. 315). Jakarta: Komunitas Bambu.

Rahman, Ansar. (2000). Perspektif Berdirinya Kota Pontianak. Pontianak: Tanpa Penerbit.Groat, L., \& Wang, D. (2002). Architectural Research Method. Canada: John Wiley and Sons, Inc.

Lombard, D. (2005). Nusa Jawa Silang Budaya, - Buku I, II, \& III. Jakarta: Gramedia Pustaka Utama.

Manguin, P. (2014). Sifat Amorf Politi-politi Pesisir Asia Tenggara Kepulauan. In P. Manguin (Ed.), Kedatuan Sriwijaya (Kedua, p. 315). Jakarta: Komunitas Bambu.

Reid, A. (2011). Asia Tenggara Dalam Kurun Niaga 1450-1680, Jilid 2: Jaringan Perdaganga Global (2nd ed.). Jakarta: Yayasan Pustaka Obor Indonesia.

Usman, S. (2011). Kota Pontianak Sedjak Tempo Doeloe: Album dan Dokumen Masa Lampau. Pontianak.

Ricklefs, M. C. (2010). Sejarah Indoensia Modern 1200-2008, Jakarta, PT. Serambi Ilmu Semesta.

Schutte, G.J, ed. (1994). State and Trade in Indonesian Archipelago, KITLV Press, Leiden

Veth, P. (2012). Borneo Bagian Barat: Geografis, Statistik, Historis Jilid 1, Terjemahan Borneo's Wester-Afdeeling Geographisch, Statistisch, Historisch 1854, terjemahan oleh P. O. C. Yeri., Pontianak, Institut Dayakologi. 